\title{
Drug-drug interactions involving antidepressants: focus on desvenlafaxine
}

This article was published in the following Dove Press journal:

Neuropsychiatric Disease and Treatment

Yvette Low'

Sajita Setia ${ }^{2}$

Graca Lima ${ }^{3}$

'Department of Pharmacy, National University of Singapore, Singapore; ${ }^{2}$ Medical Affairs, Pfizer Pte. Ltd., Singapore; ${ }^{3} \mathrm{Gl}$ lobal Medical Affairs, Asia-Pacific Region, Pfizer, Hong Kong

\begin{abstract}
Psychiatric and physical conditions often coexist, and there is robust evidence that associates the frequency of depression with single and multiple physical conditions. More than half of patients with depression may have at least one chronic physical condition. Therefore, antidepressants are often used in cotherapy with other medications for the management of both psychiatric and chronic physical illnesses. The risk of drug-drug interactions (DDIs) is augmented by complex polypharmacy regimens and extended periods of treatment required, of which possible outcomes range from tolerability issues to lack of efficacy and serious adverse events. Optimal patient outcomes may be achieved through drug selection with minimal potential for DDIs. Desvenlafaxine is a serotonin-norepinephrine reuptake inhibitor approved for the treatment of adults with major depressive disorder. Pharmacokinetic studies of desvenlafaxine have shown a simple metabolic profile unique among antidepressants. This review examines the DDI profiles of antidepressants, particularly desvenlafaxine, in relation to drugs of different therapeutic areas. The summary and comparison of information available is meant to help clinicians in making informed decisions when using desvenlafaxine in patients with depression and comorbid chronic conditions.
\end{abstract}

Keywords: desvenlafaxine, polypharmacy, comorbidities, depression, pharmacokinetics

\section{Chronic conditions and association with depression}

Major depressive disorder (MDD) is a functionally disabling condition characterized by depressed mood or loss of interest in the usual activities of daily life. ${ }^{1}$ Depression is the leading cause of disability and a major contributor to the overall global burden of disease, affecting more than 300 million people worldwide. ${ }^{2}$ There is robust evidence showing that depression is more frequent in patients with single and multiple physical disorders than in people who are in good physical health. ${ }^{3,4}$ According to the National Institute for Health and Care Excellence (NICE) guidelines, about 20\% of patients with a chronic physical condition are also suffering from depression. ${ }^{4}$ Conversely, World Health Organization World Mental Health surveys have reported that about $72 \%$ of patients with MDD have a comorbid chronic physical condition. ${ }^{5}$ The percentage prevalence of depression in patients with different chronic physical conditions is depicted in Figure 1.

\section{Polypharmacy and drug-drug interactions}

Patients with multiple comorbidities often take many medications, and are exposed to the risk of drug-drug interactions (DDIs). ${ }^{6}$ These are frequently caused by pharmacodynamic (PD) or pharmacokinetic (PK) interactions between different agents. ${ }^{7}$ In PD interactions, one drug may alter the pharmacological actions of another drug through new, additive, synergistic, or antagonistic effects. ${ }^{7}$ In PK interactions,
Medical Affairs, Pfizer Pte. Ltd., 80 Pasir

Panjang Road - 16-81/82, Mapletree

Business City, Singapore 117372

Tel +6564038754

Fax +6567224188

Email sajita.setia@pfizer.com 


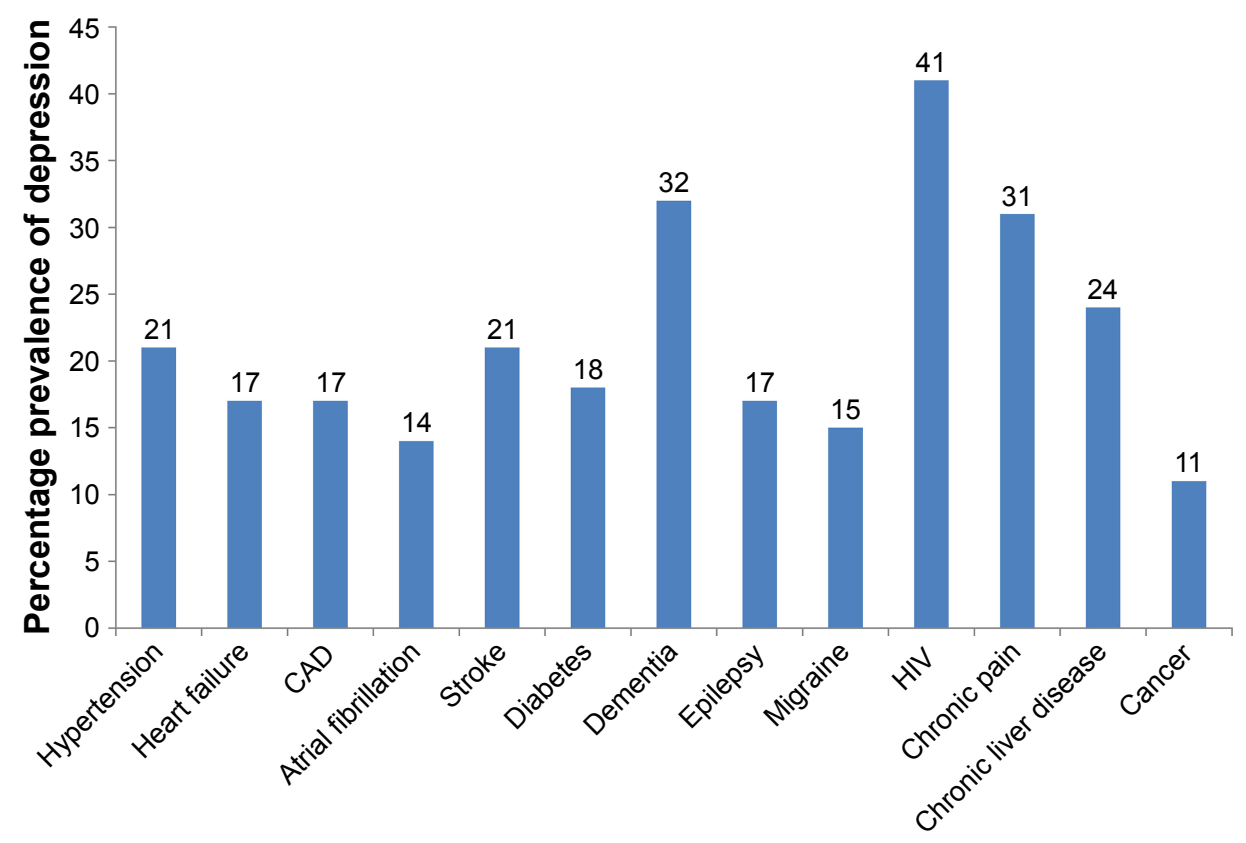

Figure I Prevalence of depression in patients with chronic physical conditions.

Notes: Data from: Dumbreck et al $2015^{35}$ (diabetes, heart failure), Guthrie et al $2012^{49}$ (atrial fibrillation, chronic pain, CAD, dementia, hypertension, stroke), Kalaydjian and Merikangas $^{59}$ (migraine), $\mathrm{Ng}$ et al ${ }^{107}$ (cancer), Tao et al ${ }^{75}$ (HIV), Tellez-Zenteno et al ${ }^{54}$ (epilepsy), and Weinstein et al ${ }^{100}$ (chronic liver disease).

Abbreviation: CAD, coronary artery disease.

one drug affects the absorption, distribution, metabolism, or excretion of another concomitant drug. ${ }^{7}$ Most DDIs involve PK interactions through impairment of drug elimination by interfering with hepatic metabolism, renal excretion, or transcellular transport. ${ }^{8}$ Hepatic cytochrome P450 (CYP) enzymes are essential for metabolism of most medications, including many antidepressants. ${ }^{9,10}$ Although there are more than 50 isoenzymes in the CYP superfamily, six of them metabolize $90 \%$ of drugs, with the two most significant being CYP2D6 and CYP3A4. ${ }^{10}$ Nearly 50\% of psychiatric and geriatric patients have been found to use at least one drug metabolized by CYP2D6, and $62 \%$ of these drugs were either antidepressants or antipsychotics. ${ }^{11}$

The genes for some CYP enzymes exhibit polymorphism, producing interindividual variability in metabolic capacity. ${ }^{12}$ For instance, extensive (normal), intermediate, poor, and ultrarapid metabolizer phenotypes have been identified for CYP2D6. ${ }^{12}$ Poor metabolizers have no functional CYP2D6 alleles, and may experience drug-induced adverse events or suboptimal clinical response. ${ }^{12}$ In many ways, the clinical effect of drug metabolism in poor CYP2D6 metabolizers may be similar to DDIs related to CYP2D6 inhibition. ${ }^{12}$ Furthermore, polypharmacy including CYP2D6 substrates/ inhibitors may induce CYP2D6 phenoconversion. ${ }^{13}$ As such, the predictability of the pharmacologic effect of a drug may remain uncertain in these scenarios.
Nevertheless, knowledge of pharmacogenomics based on patient genotype can be used to predict drug metabolism and hence individualize drug therapy. ${ }^{14}$ However, the clinical and economic advantages of pharmacogenetic testing remain unclear. ${ }^{15}$ Therefore, currently there are no formal recommendations to conduct this testing prior to initiating antidepressant treatment. ${ }^{15}$

The DDIs that result in complicated outcomes, such as an increase of serious adverse reactions, lack of efficacy, or tolerability issues, may be clinically significant. ${ }^{16,17}$ This however is also influenced by several factors, such as a compromised metabolic pathway due to renal disease, liver disease, or poor/intermediate CYP-metabolizing status or therapeutic index of medicine. ${ }^{16}$ The clinical relevance of many DDIs is easily underestimated, as detection is challenging and possible outcomes may vary widely. ${ }^{17}$ Therefore, it is critical to avoid DDIs where possible through selection of appropriate medications with the least potential for DDIs.

\section{Desvenlafaxine Efficacy and tolerability}

Desvenlafaxine succinate is a serotonin-norepinephrine reuptake inhibitor (SNRI) approved for the treatment of MDD in adults at a recommended dose of $50 \mathrm{mg} /$ day. ${ }^{18}$ Analysis from nine fixed-dose, short-term, placebo-controlled studies 
in adult outpatients with MDD showed statistically significant improvements with desvenlafaxine 50 and $100 \mathrm{mg} /$ day versus placebo for all efficacy end points. ${ }^{19}$ A few head-to-head studies have also shown comparable efficacy and safety of desvenlafaxine versus escitalopram..$^{20-22}$

Desvenlafaxine is recommended with level 1 evidence by the American Psychiatric Association 2010 guidelines. $^{23}$ Canadian Network for Mood and Anxiety Treatments 2009 and 2016 guidelines also recommended it as one of the first-line antidepressants for MDD. ${ }^{24,25}$ Australian and New Zealand College of Psychiatrists 2015 practice guidelines recommended desvenlafaxine over other antidepressants, which are metabolized by the liver for patients with hepatic impairments. ${ }^{26}$

\section{Metabolism and elimination}

Desvenlafaxine (or $O$-desmethylvenlafaxine) is the major active metabolite of the SNRI venlafaxine after metabolism by CYP2D6. This metabolite has antidepressant activity, and its salt, desvenlafaxine succinate, is an approved drug. ${ }^{27}$ Renal excretion is an important route of desvenlafaxine elimination, with around $45 \%$ eliminated unchanged in the urine. ${ }^{18,28}$ Its metabolism primarily involves the non-CYP enzymes UGTs to form its glucuronide metabolite, which is also renally excreted. ${ }^{18,28}$ The UGTs are a family of enzymes involved in detoxification and inactivation of compounds, and their activity is generally spared in liver disease. ${ }^{29,30}$ The minor hepatic metabolic pathway involves CYP3A4 $(<5 \%){ }^{18,31}$ This hepatic metabolism has been shown to play a limited role in desvenlafaxine elimination, indicating a relatively uncomplicated metabolism. ${ }^{31}$ On the other hand, with the concern that desvenlafaxine is predominantly renally excreted, prescribing information states that desvenlafaxine doses above the $50 \mathrm{mg}$ /day recommended therapeutic dose should not be used in patients with moderate-severe renal impairment or end-stage renal disease. ${ }^{18,31}$ Results from PK studies have demonstrated decreasing systemic clearance of single oral $100 \mathrm{mg}$ desvenlafaxine with severity of renal impairment. ${ }^{32}$ However, urinary recovery of total desvenlafaxine and its metabolites are similar in renal impaired versus healthy patients. ${ }^{32}$

Desvenlafaxine may have a low risk of variability in pharmacologic effect resulting from CYP2D6 polymorphisms or DDIs when coadministered with CYP2D6 substrates or inhibitors. ${ }^{12,14}$ Table 1 depicts the relationship between other antidepressants and CYP enzymes, in addition to desvenlafaxine. ${ }^{23,33,34}$

\section{Potential DDls with antidepressants}

Dumbreck et al conducted a systematic examination of the NICE guidelines for potentially serious DDIs between drugs recommended for depression and eleven other common conditions..$^{35}$ Among recommended antidepressants, 89 potentially serious DDI pairs were identified, with bleeding risk as the most common, particularly with selective serotonin-reuptake inhibitors (SSRIs). Other potential DDIs included lithium toxicity with SSRIs, ventricular arrhythmias with tricyclic antidepressants (TCAs), and central nervous system toxicity with TCAs and monoamine oxidase inhibitors (MAOIs).

Current evidence-based guidelines for both physical diseases and psychiatric disorders have been criticized for their lack of applicability to patients with comorbid conditions. ${ }^{36}$ However, insufficient evidence is available to formulate guidelines for many diverse combinations of comorbidities. ${ }^{17,37}$ The following section highlights potential DDIs when antidepressants are administered concomitantly in patients with comorbid chronic physical conditions. We have prioritized the chronic conditions based on Figure 1 (conditions with relatively higher prevalence rates of depression). Table 2 summarizes the potential DDIs between desvenlafaxine and drugs in each therapeutic class for treating the chronic conditions discussed.

\section{Cardiovascular conditions}

Cardiovascular (CV) conditions and depression frequently coexist. ${ }^{38}$ Prevalence rates of MDD in the different $\mathrm{CV} /$ metabolic conditions are illustrated in Figure 1. $\beta$-Blockers like propranolol, timolol, metoprolol, and carvedilol are metabolized extensively by CYP enzymes, including CYP2D6 ${ }^{39}$ Antidepressants that are potent CYP2D6 inhibitors, eg, paroxetine, fluoxetine, duloxetine, and bupropion, have been found to cause additional reductions in heart rate when administered with propranolol. ${ }^{39}$ Clinically significant bradycardia has been reported with coadministration of paroxetine/fluoxetine and metoprolol ${ }^{40}$ Other antihypertensives, such as calcium-channel blockers are substrates and inhibitors of CYP3A4. ${ }^{39}$ When calcium-channel blockers are coadministered with CYP3A4 inhibitors, there is a risk of hypotension and bradycardia. ${ }^{10}$ Similar PK mechanisms are involved in DDIs in hypercholesterolemia treatment. The risk of myopathy is greater when metabolism of statins is repressed by CYP3A4 inhibitors. ${ }^{10}$ Also, most antiarrhythmic agents, which have narrow therapeutic indices, are metabolized via CYP enzymes and prone to interactions with 
Table I Antidepressants and CYP enzymes

\begin{tabular}{|c|c|c|c|}
\hline Antidepressants & $\begin{array}{l}\text { Major } \\
\text { elimination } \\
\text { pathway }\end{array}$ & Other elimination pathways & Inhibitory effect on CYP isoenzyme \\
\hline \multicolumn{4}{|l|}{ SSRI } \\
\hline Citalopram & CYP2CI9 & CYP3A4, CYP2D6 & CYPIA2, CYP2B6, CYP2C19, CYP2D6 \\
\hline Escitalopram & CYP2CI9 & CYP3A4, CYP2D6 & CYP2D6, CYP2C9 \\
\hline $\begin{array}{l}\text { Fluoxetine (active metabolite } \\
\text { norfluoxetine) }\end{array}$ & CYP2D6 & CYP2C9, CYP2CI9, CYP3A4 & CYP2D6,** CYP2C9,* CYP2C19,* CYP3A4,* CYPIA2 \\
\hline Fluvoxamine & $\begin{array}{l}\text { CYPIA2, } \\
\text { CYP2D6 }\end{array}$ & & CYPIA2,** CYP2C19,** CYP2C9,* CYP3A4,* CYP2D6 \\
\hline Paroxetine & CYP2D6 & CYP3A4 & CYP2D6,** CYPIA2, CYP2C9, CYP2C19, CYP3A4 \\
\hline Sertraline & CYP2B6 & CYP2C19, CYP2C9, CYP3A4, CYP2D6 & CYP2D6,* CYPIA2, CYP2C9, CYP2C19, CYP3A4 \\
\hline \multicolumn{4}{|l|}{ SNRI } \\
\hline Desvenlafaxine & Renal & UGT, CYP3A4 & None \\
\hline Duloxetine & CYPIA2 & CYP2D6 & CYP2D6* \\
\hline Levomilnacipran & Renal & $\begin{array}{l}\text { CYP3A4, CYP2C8, CYP2C19, } \\
\text { CYP2D6, CYP2J2, UGT }\end{array}$ & None \\
\hline Milnacipran & Renal & UGT, CYP3A4 & CYP3A4 \\
\hline $\begin{array}{l}\text { Venlafaxine (active } \\
\text { metabolite desvenlafaxine) }\end{array}$ & CYP2D6 & CYP3A4 & CYP2D6, CYP3A4 \\
\hline \multicolumn{4}{|l|}{ Others } \\
\hline Agomelatine & CYPIA2 & CYP2C9, CYP2CI9 & None \\
\hline $\begin{array}{l}\text { Bupropion (active metabolite } \\
\text { hydroxybupropion) }\end{array}$ & CYP2B6 & & CYP2D6* \\
\hline Mirtazapine & $\begin{array}{l}\text { CYP2D6, } \\
\text { CYP3A4 }\end{array}$ & CYPIA2, UGT & None \\
\hline Reboxetine & CYP3A4 & & None \\
\hline Vilazodone & CYP3A4 & CYP2C19, CYP2D6, carboxylesterase & CYP2C8? \\
\hline Vortioxetine & CYP2D6 & $\begin{array}{l}\text { CYP3A4, CYP2C19, CYP2C9, } \\
\text { CYP2A6, CYP2C8, CYP2B6 }\end{array}$ & None \\
\hline
\end{tabular}

Notes: **Potent; *moderate; 'undetermined; no symbol, weak. Data from Flockhart, ${ }^{33}$ Gelenberg et al, ${ }^{23}$ and Spina et al. ${ }^{34}$

Abbreviations: CYP, cytochrome P450; SNRI, serotonin-norepinephrine reuptake inhibitor; SSRI, selective serotonin-reuptake inhibitor; UGT, uridine diphosphate glucuronosyltransferases.

CYP inhibitors. ${ }^{41}$ There are consistent reports of DDIs with warfarin and multiple agents, including SSRIs. ${ }^{10}$ Warfarin is a substrate of CYP3A4, CYP1A2, and CYP2C9 and can upregulate CYP3A4 and 2C9. ${ }^{42}$ A recent study investigating the effect of CYP2C9-mediated warfarin-SSRI interaction, however, revealed comparable clinical outcomes, showing that SSRIs with CYP2C9 inhibition (eg, fluvoxamine and fluoxetine) may not affect warfarin-treatment outcomes if patients are closely monitored. ${ }^{43}$ Of the newer oral thrombin inhibitors, rivaroxaban and apixaban are contraindicated in combination with drugs that inhibit CYP3A4. ${ }^{44}$ These include antidepressants like fluvoxamine (Table 1).

Although desvenlafaxine may be helpful in avoiding most PK interactions, there are some PD interactions with CV medications (Table 2). First, caution is advised in patients with CV or lipid-metabolism disorders, as elevation in blood pressure, heart rate, and cholesterol levels has been observed in clinical studies with desvenlafaxine. ${ }^{18}$ Second, due to antiplatelet effects of the serotonergic mechanism, there is a need to exercise caution with regard to abnormal bleeding risks with concomitant desvenlafaxine and aspirin, antiplatelets, or other drugs that affect coagulation. ${ }^{4,18}$ Abnormal bleeding risk is also associated with concomitant SSRIs and antiplatelet agents, and likewise caution is advised. ${ }^{4}$

\section{Diabetes mellitus}

Depression is a common morbidity in diabetes mellitus, being twice as common in patients with diabetes mellitus than in the general population. ${ }^{45,46}$ Depression in diabetic patients is often treated with antidepressants. ${ }^{45}$ However, there have been some reports of hypoglycemia associated with antidepressants (eg, SSRIs and MAOIs).,45

One postulated mechanism is related to CYP2C9 inhibition. Sulfonylureas and nateglinide are substrates of CYP2C9, while several SSRIs are inhibitors of this enzyme (Table 1). ${ }^{14}$ A decrease in total clearance of tolbutamide has been found during treatment with fluvoxamine. ${ }^{47}$ Increased PD effects of sulfonylureas and increased risk of hypoglycemia have also been reported when glibenclamide, glimepiride, or glipizide was coadministered with other CYP2C9 inhibitors. ${ }^{48}$ 
Table 2 Summary of potential DDIs with desvenlafaxine

\begin{tabular}{|c|c|c|}
\hline Therapeutic class/drugs & $\begin{array}{l}\text { Pharmacologic profile of } \\
\text { polypharmacy agents }\end{array}$ & Potential DDI with desvenlafaxine \\
\hline \multicolumn{3}{|l|}{ Cardiovascular conditions } \\
\hline $\begin{array}{l}\beta \text {-blockers (eg, propranolol, timolol, } \\
\text { metoprolol, carvedilol) }\end{array}$ & Substrate of CYP2D6 $6^{39}$ & $\begin{array}{l}\text { No interaction expected, }{ }^{a} \text { but caution is still advised, as } \\
\text { elevation in blood pressure, heart rate, and cholesterol levels } \\
\text { was observed in clinical studies }{ }^{18}\end{array}$ \\
\hline $\begin{array}{l}\text { CCBs, statins (eg, lovastatin, } \\
\text { simvastatin, atorvastatin), } \\
\text { rivaroxaban, apixaban }\end{array}$ & Substrate of CYP3A4 $4^{10,39,44}$ & $\begin{array}{l}\text { No interaction expected, }{ }^{a} \text { but caution is still advised, as } \\
\text { elevation in blood pressure, heart rate, and cholesterol levels } \\
\text { was observed in clinical studies }{ }^{18}\end{array}$ \\
\hline $\begin{array}{l}\text { Antiarrhythmic agents (eg, quinidine, } \\
\text { disopyramide, lignocaine, mexiletine, } \\
\text { flecainide, amiodarone, dronedarone) }\end{array}$ & $\begin{array}{l}\text { Substrate, inducer, or inhibitor of } \\
\text { various CYP enzymes }{ }^{41}\end{array}$ & $\begin{array}{l}\text { Potent CYP3A4 inhibitors may result in higher levels of } \\
\text { desvenlafaxine }{ }^{18} \\
\text { Effect of CYP3A4 induction is unknown }{ }^{\text {b }}\end{array}$ \\
\hline Warfarin & $\begin{array}{l}\text { Substrate of CYP3A4, CYPIA2 and } \\
\text { CYP2C9; induction of CYP3A4 and } \\
\text { CYP2C } 9^{42}\end{array}$ & $\begin{array}{l}\text { Risk of abnormal bleeding, caution with concomitant aspirin, } \\
\text { antiplatelet drugs, or other drugs that affect coagulation }{ }^{10,18} \\
\text { Effect of CYP3A4 induction is unknown, but may decrease } \\
\text { levels of desvenlafaxine }\end{array}$ \\
\hline
\end{tabular}

\section{Diabetes mellitus}

\begin{tabular}{lll}
\hline Sulfonylureas (eg, tolbutamide, & Substrate of CYP2C914 No interaction expected, ${ }^{a}$ but caution is still advised, as
\end{tabular}

glipizide), nateglinide

Neurological conditions

Dementia

\begin{tabular}{|c|c|c|}
\hline Donepezil, galantamine & Substrate of CYP2D6 and CYP3A451 & No interaction expected ${ }^{a}$ \\
\hline Memantine & Renally excreted by tubular secretion ${ }^{52}$ & Effect on tubular secretion is unknown ${ }^{b}$ \\
\hline \multicolumn{3}{|l|}{ Epilepsy } \\
\hline $\begin{array}{l}\text { Carbamazepine, phenobarbital, } \\
\text { phenytoin, primidone }\end{array}$ & $\begin{array}{l}\text { Induction of CYP enzymes } \\
\text { (eg, CYPIA2, CYP3A4) and UGTs } \\
\text { (eg, UGTIAI, UGT2B7, and } \\
\text { UGT2BI5) }{ }^{34}\end{array}$ & $\begin{array}{l}\text { Interaction not studied, but unlikely to be relevant according } \\
\text { to CYP involvement in metabolism } \\
\text { Effect of UGT induction is unknown, but may decrease levels } \\
\text { of desvenlafaxine }{ }^{\text {b }}\end{array}$ \\
\hline Valproic acid & $\begin{array}{l}\text { Inhibition of CYPs (eg, CYP2C9, } \\
\text { CYP2CI9 and CYP3A4), some UGTs } \\
\text { (eg, UGTIA4 and UGT2B7) }^{34}\end{array}$ & $\begin{array}{l}\text { Potent CYP3A4 inhibitors may result in higher levels of } \\
\text { desvenlafaxine } \\
18, b\end{array}$ \\
\hline $\begin{array}{l}\text { Carbamazepine, phenytoin, } \\
\text { phenobarbital, primidone }\end{array}$ & Substrate of CYP3A4 or CYP2C934 & No interaction expected ${ }^{a}$ \\
\hline Lamotrigine, topiramate & Induction of UGTs and/or CYP3A4 $4^{34}$ & $\begin{array}{l}\text { Effect of CYP3A4 and UGT induction is unknown, but may } \\
\text { decrease levels of desvenlafaxine }{ }^{b}\end{array}$ \\
\hline Bupropion, TCAs & Strong proconvulsive properties ${ }^{53,57}$ & $\begin{array}{l}\text { Possibility of seizures, caution in patients with seizure } \\
\text { disorder }{ }^{18}\end{array}$ \\
\hline \multicolumn{3}{|l|}{ Migraine } \\
\hline Triptans & $\begin{array}{l}\text { Affinity for } 5 \mathrm{HT} \text {, receptor } \\
{\text { (serotonergic property })^{66}}^{\text {sergen }}\end{array}$ & $\begin{array}{l}\text { Possibility of serotonin syndrome, caution when } \\
\text { coadministered with serotonergic agents }{ }^{8,67}\end{array}$ \\
\hline Sumatriptan, zolmitriptan & Substrate of $\mathrm{MAOA}^{61}$ & No interaction expected ${ }^{\mathrm{a}}$ \\
\hline Frovatriptan, eletriptan & Substrate of CYPIA2 or CYP3A461,62 & No interaction expected ${ }^{\mathrm{a}}$ \\
\hline \multicolumn{3}{|l|}{ Schizophrenia } \\
\hline $\begin{array}{l}\text { FGAs (eg, phenothiazines), } \\
\text { asenapine (SGA) }\end{array}$ & Inhibition of CYP2D669,72 & $\begin{array}{l}\text { No interaction expected, abut caution for serotonin syndrome } \\
\text { when coadministered with antidopaminergic agents }{ }^{18}\end{array}$ \\
\hline SGAs, apart from amisulpride & $\begin{array}{l}\text { Substrate of various CYP enzymes } \\
\text { (eg, CYP2D6, CYP3A4) and UGTs }{ }^{69}\end{array}$ & $\begin{array}{l}\text { No PK DDI was shown between desvenlafaxine and } \\
\text { aripiprazole }^{18}\end{array}$ \\
\hline Clozapine & Associated with hypertension ${ }^{69}$ & $\begin{array}{l}\text { Increased risk for tachycardia and/or hypertension when } \\
\text { administered with desvenlafaxine } \mathrm{e}^{69, \mathrm{~b}}\end{array}$ \\
\hline \multicolumn{3}{|l|}{ HIV } \\
\hline Protease inhibitors (eg, ritonavir) & $\begin{array}{l}\text { Inhibition of CYP3A4 and/or } \\
\text { CYP2D } 66^{77,78}\end{array}$ & $\begin{array}{l}\text { Potent CYP3A4 inhibitors may result in higher levels of } \\
\text { desvenlafaxine }{ }^{18, b}\end{array}$ \\
\hline Efavirenz & $\begin{array}{l}\text { Inhibition of CYP2CI9; induction of } \\
\text { CYP3A4 and CYP2D677 }\end{array}$ & No interaction expected ${ }^{\mathrm{a}}$ \\
\hline Nevirapine & $\begin{array}{l}\text { Substrate and inducer of CYP3A4 and } \\
\text { CYP2B6 }\end{array}$ & $\begin{array}{l}\text { Effect of CYP3A4 induction is unknown, but may decrease } \\
\text { levels of desvenlafaxine }{ }^{b}\end{array}$ \\
\hline Indinavir & Substrate and inhibitor of CYP3A4 ${ }^{80}$ & $\begin{array}{l}\text { No PK DDI was shown between desvenlafaxine and } \\
\text { indinavir }\end{array}$ \\
\hline
\end{tabular}
hypoglycemic events reported with other antidepressants ${ }^{45}$ 
Table 2 (Continued)

\begin{tabular}{|c|c|c|}
\hline Therapeutic class/drugs & $\begin{array}{l}\text { Pharmacologic profile of } \\
\text { polypharmacy agents }\end{array}$ & Potential DDI with desvenlafaxine \\
\hline \multicolumn{3}{|l|}{ Chronic pain } \\
\hline \multicolumn{3}{|l|}{ Opioids } \\
\hline $\begin{array}{l}\text { Codeine, fentanyl, methadone, } \\
\text { morphine, oxycodone, pethidine, } \\
\text { tramadol }\end{array}$ & $\begin{array}{l}\text { Substrate of CYP3A4 and/or } \\
\text { CYP2D66 }\end{array}$ & No interaction expected ${ }^{a}$ \\
\hline $\begin{array}{l}\text { Fentanyl, methadone, pethidine, } \\
\text { tramadol }\end{array}$ & $\begin{array}{l}\text { Inhibition of serotonin reuptake } \\
\text { (serotonergic property) }^{63}\end{array}$ & $\begin{array}{l}\text { Possibility of serotonin syndrome, caution when } \\
\text { coadministered with serotonergic agents }^{18,63}\end{array}$ \\
\hline \multicolumn{3}{|l|}{ NSAIDs } \\
\hline $\begin{array}{l}\text { Ibuprofen, naproxen, diclofenac, } \\
\text { celecoxib, etoricoxib }\end{array}$ & $\begin{array}{l}\text { Substrate of several CYP enzymes } \\
\text { including CYP3A4, CYP2C9, or } \\
\text { CYP2D691-96 }\end{array}$ & No interaction expected ${ }^{a}$ \\
\hline $\begin{array}{l}\text { Ibuprofen, indomethacin, } \\
\text { diclofenac, meloxicam, celecoxib }\end{array}$ & $\begin{array}{l}\text { Inhibition of CYP2C9 or } \\
\text { CYP2C8/2D691 }\end{array}$ & No interaction expected ${ }^{\mathrm{a}}$ \\
\hline Ibuprofen, diclofenac & Inhibition of UGT' & $\begin{array}{l}\text { Effect of UGT inhibition unknown, but may increase levels of } \\
\text { desvenlafaxine }{ }^{b}\end{array}$ \\
\hline All NSAIDs & Risk of gastrointestinal bleeding9l & $\begin{array}{l}\text { Caution for abnormal bleeding with concomitant aspirin, } \\
\text { antiplatelet drugs, or other drugs that affect coagulation }{ }^{18}\end{array}$ \\
\hline \multicolumn{3}{|l|}{ Chronic liver disease } \\
\hline $\mathrm{IFN} \alpha$ & Inhibition of CYPIA2 ${ }^{103}$ & No interaction expected ${ }^{\mathrm{a}}$ \\
\hline $\begin{array}{l}\text { Direct-acting antivirals, such as } \\
\text { ritonavir, boceprevir, simeprevir }\end{array}$ & Inhibition of CYP3A4 104,105 & $\begin{array}{l}\text { Potent CYP3A4 inhibitors may result in higher levels of } \\
\text { desvenlafaxine }{ }^{18, b}\end{array}$ \\
\hline Simeprevir, asunaprevir & Substrate of CYP3A4/5 128,129 & No interaction expected ${ }^{\mathrm{a}}$ \\
\hline Ombitasvir, dasabuvir, paritaprevir & Inhibition of UGTs ${ }^{104}$ & $\begin{array}{l}\text { May increase desvenlafaxine levels (clinical significance } \\
\text { unknown); monitor and titrate dose according to clinical } \\
\text { response }{ }^{106}\end{array}$ \\
\hline \multicolumn{3}{|l|}{ Cancer } \\
\hline \multicolumn{3}{|l|}{ Antiemetic agents } \\
\hline $\begin{array}{l}5 \mathrm{HT}_{3} \text {-receptor antagonists } \\
\text { (ondansetron, tropisetron, } \\
\text { dolasetron, palonosetron) }\end{array}$ & Substrate of CYP2D6"II & No interaction expected ${ }^{a}$ \\
\hline $\begin{array}{l}\text { Granisetron, corticosteroids } \\
\text { (dexamethasone, } \\
\text { methylprednisolone, prednisolone, } \\
\text { prednisone) }\end{array}$ & Substrate of CYP3A4109,111 & No interaction expected ${ }^{\mathrm{a}}$ \\
\hline Dexamethasone, prednisone & Induction of CYP3A4 $4^{109}$ & $\begin{array}{l}\text { Effect of CYP3A4 induction is unknown, but may decrease } \\
\text { levels of desvenlafaxine }{ }^{b}\end{array}$ \\
\hline \multicolumn{3}{|l|}{ Anticancer agents } \\
\hline $\begin{array}{l}\text { Vinca alkaloids (eg, vincristine, } \\
\text { vinblastine, vinorelbine), taxanes } \\
\text { (eg, docetaxel, paclitaxel), } \\
\text { tyrosine-kinase inhibitors } \\
\text { (eg, erlotinib, gefitinib, imatinib), } \\
\text { irinotecan }\end{array}$ & Substrate of CYP3A4 $4^{|| 1,|| 12,|15,||16,| 26}$ & No interaction expected ${ }^{a}$ \\
\hline Erlotinib & Substrate of CYPIA2115 & No interaction expected \\
\hline Cyclophosphamide, ifosfamide & Substrate of CYP3A4 and CYP2B6 ${ }^{119}$ & No interaction expected ${ }^{a}$ \\
\hline Doxorubicin & Substrate of CYP3A4 and CYP2D6 ${ }^{120}$ & No interaction expected ${ }^{\mathrm{a}}$ \\
\hline Tamoxifen & Substrate of CYP2D6 ${ }^{121}$ & $\begin{array}{l}\text { No interaction documented; desvenlafaxine may represent } \\
\text { a safe and effective treatment unlikely to alter the efficacy of } \\
\text { tamoxifen }{ }^{125}\end{array}$ \\
\hline Imatinib, gefitinib, irinotecan & $\begin{array}{l}\text { Inhibition of CYP3A4/5, CYP2D6, } \\
\text { and/or CYP2C9 } 111,116,117,126\end{array}$ & $\begin{array}{l}\text { Potent CYP3A4 inhibitors may result in higher levels of } \\
\text { desvenlafaxine } \mathrm{e}^{18, \mathrm{~b}}\end{array}$ \\
\hline \multicolumn{3}{|c|}{ 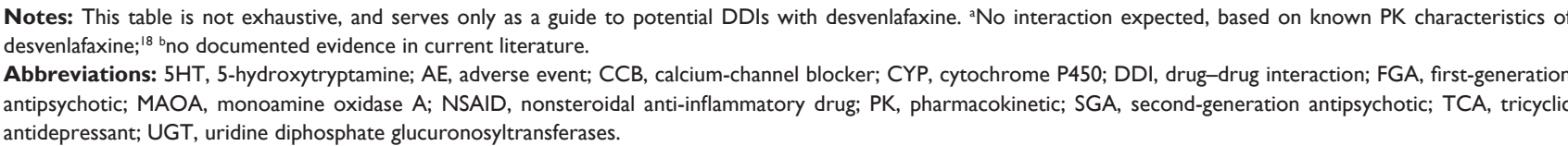 } \\
\hline
\end{tabular}


Therefore, it is suggested that concomitant use of CYP2C9 inhibitors (eg, sertraline, fluoxetine, and fluvoxamine) and sulfonylureas or nateglinide be avoided, due to the potential risk of hypoglycemia. ${ }^{14}$

Other postulated mechanisms include possible increase in insulin sensitivity after long-term use of antidepressants with high affinity for the serotonin-reuptake transporter or depression itself predisposing to impairment of glucose control. ${ }^{45}$ Although no association has been shown between antidepressant use in diabetic patients and an increased risk of hypoglycemia requiring hospitalization, a trend for higher risk of hypoglycemia was identified in antidepressants with high affinity for the serotonin-reuptake transporter. ${ }^{45}$ Other than the regular blood-glucose monitoring to prevent hypoglycemia, ${ }^{45}$ SNRIs, mirtazapine, and reboxetine have been identified as alternative antidepressants for management of depression in diabetes. ${ }^{4}$

\section{Neurological conditions \\ Dementia}

The comorbid prevalence of depression in dementia patients has been reported as $32 \% .^{49}$ In a study at a dementia-management center, DDIs involving antidepressants were responsible for $6.1 \%$ of adverse events. ${ }^{50}$ Donepezil and galantamine are metabolized through CYP2D6 and 3A4, and may be affected by specific inhibitors of those enzymes. ${ }^{51}$ Coadministration of paroxetine (potent CYP2D6 inhibitor) has been found increase to galantamine exposure by $40 \% .{ }^{51}$ Memantine is excreted unchanged in urine, but may have decreased clearance when coadministered with medications that interfere with tubular secretion. ${ }^{52}$

\section{Epilepsy}

In patients with epilepsy, MDD is the most common psychiatric illness, at a lifetime prevalence rate of $17.4 \% .^{53,54}$ Apart from managing seizures, antiepileptic drugs are also increasingly prescribed for nonepileptic conditions, such as neuropathic pain and migraine. ${ }^{34}$ In general, PK interactions with antiepileptic drugs are well documented and recognized. Phenytoin, carbamazepine, and barbiturates are potent inducers of CYP enzymes and UGTs, potentially decreasing the exposure of some antidepressants (Table 1). ${ }^{34,53}$ Valproic acid is a broad-spectrum inhibitor of various enzymes, including CYPs and some UGTs. ${ }^{34}$ On the other hand, many antidepressants also inhibit CYP metabolism to varying degrees (Table 1) and can elevate antiepileptic-drug levels. ${ }^{53}$ Among the newer antiepileptic drugs, only lamotrigine and topiramate have inductive effects on CYP enzymes. ${ }^{55,56}$ As such, in the polypharmacy of antidepressants and antiepileptic drugs, selection of antidepressants with minimal potential for PK interactions is highly recommended. ${ }^{53,57}$ There have been no reports that SNRIs, including desvenlafaxine, affect the PK of antiepileptic drugs. ${ }^{34}$

However, some antidepressants may potentially have a PD interaction with antiepileptic agents, lowering seizure thresholds and exacerbating seizure attacks. ${ }^{53}$ Studies have shown that seizure risk varies by dose and drug, and hence antidepressants with the strongest proconvulsive properties (eg, bupropion and TCAs) should be avoided in epileptic patients. ${ }^{53,57}$ Desvenlafaxine has not been systematically evaluated in patients with seizure disorders, and should be prescribed with care in these patients. ${ }^{18}$

\section{Migraine}

Several studies have shown strong associations between migraine and MDD. ${ }^{58}$ Depression has been found to be nearly three times more common in patients with severe headaches/ migraine. ${ }^{59}$ Sumatriptan and zolmitriptan are metabolized by monoamine oxidase A (MAOA), and thus coadministration with MAOIs can potentiate the side effects of triptans. ${ }^{60,61}$ Frovatriptan is eliminated mainly by CYP1A2 ${ }^{61}$ Eletriptan is primarily metabolized by CYP3A4, and CYP3A4 inhibitors (Table 1) have been labeled as contraindicated. ${ }^{62}$

The frequency of triptan-SSRI coprescription was about $20 \%$ in a study examining triptan prescriptions. ${ }^{62}$ However, there are debatable concerns regarding the safety and PD interactions of this coprescription. ${ }^{63-65}$ Pharmacologically, triptans demonstrate only weak affinity for 5-hydroxytryptamine $1\left(5 \mathrm{HT}_{1}\right)$ receptors and no activity at $5 \mathrm{HT}_{2}$ receptors, ${ }^{66}$ which are believed to be mechanistically implicated in the development of serotonin syndrome. ${ }^{65}$ However in 2010, the US Food and Drug Administration recommended that patients treated concomitantly with a triptan and SSRI/SNRI be informed of the possibility of serotonin syndrome. ${ }^{67}$ In the same year, the American Headache Society position paper stated that inadequate data were available to determine the risk of serotonin syndrome with concomitant triptan and SSRIs/SNRIs. ${ }^{64}$ Given the severity of serotonin syndrome, clinicians are still advised to be vigilant of symptoms of the toxicity. ${ }^{64}$ For desvenlafaxine, serotonin syndrome is a precaution when coadministered with serotonergic agents, such as triptans. ${ }^{18}$

\section{Schizophrenia}

Second-generation antipsychotics (SGAs) and newer antidepressants are often prescribed together in patients with 
concomitant psychotic and depressive symptoms, such as those with schizoaffective disorder or psychotic depression. ${ }^{68}$ Apart from amisulpride, SGAs are extensively metabolized through CYP enzymes, and some also by glucuronidation. ${ }^{69}$ This makes SGAs prone to PK interactions with CYP inhibitors (Table 1). For example, there have been reports of akathisia and parkinsonian symptoms during coadministration of fluoxetine and risperidone, presumably due to inhibition of CYP2D6 by fluoxetine. ${ }^{70}$ Also, PK studies and case reports have demonstrated increases in clozapine plasma levels attributed to CYP1A2 and CYP3A4 inhibition by fluvoxamine. ${ }^{69}$ Another study showed that citalopram administration had no effect on plasma levels of clozapine or risperidone. ${ }^{71}$ Desvenlafaxine $100 \mathrm{mg}$ daily does not affect the PK of a single $5 \mathrm{mg}$ dose of aripiprazole (substrate of CYP2D6 and 3A4). ${ }^{70}$

Except for asenapine (mild CYP2D6 inhibitor), SGAs appear to affect the activity of CYP enzymes insignificantly. ${ }^{72,73}$ First-generation antipsychotics (FGAs), such as phenothiazines, however, are potent CYP2D6 inhibitors, and may interact with concomitant antidepressants, such as paroxetine or venlafaxine. ${ }^{69}$ Additionally, there is a PD interaction of concern. Among all SGAs, only clozapine is associated with hypertension (usually $<5 \%$ ). ${ }^{68}$ Caution is advised to monitor the risk for tachycardia and/or hypertension during coadministration of clozapine and SNRIs, including desvenlafaxine. ${ }^{68}$

\section{Human immunodeficiency virus}

HIV has now transitioned into a nonfatal chronic condition, due to improved access to highly active antiretroviral therapy (HAART) ${ }^{74}$ However, comorbidity with incommunicable diseases, including mental disorders in HIV, has become increasingly common. ${ }^{74}$ The pooled prevalence of HIV and comorbid depression has been found to be up to $41 \%{ }^{75}$

There have been several case reports of serotonin syndrome with coadministration of fluoxetine and various HAARTs. ${ }^{76}$ Based on PK mechanisms, protease inhibitors are known CYP3A4 inhibitors, and ritonavir also inhibits CYP2D6. ${ }^{77,78}$ As such, ritonavir is expected to produce large increases in the exposure of drugs metabolized by CYP. ${ }^{78}$ A PK study of escitalopram showed statistically significant changes in some PK parameters after coadministration of single-dose ritonavir, although overall results concluded no clinical relevance. ${ }^{79}$ In another study, single-dose indinavir (substrate and inhibitor of CYP3A4) before and after 10 days of desvenlafaxine $50 \mathrm{mg}$ daily showed no PK interaction between the two agents. ${ }^{80,81}$
Reverse-transcriptase inhibitors like efavirenz have been shown to inhibit CYP2C19 and induce CYP3A4 and CYP2D6, potentially affecting levels of sertraline, citalopram, and bupropion. ${ }^{77}$ Interactions of nevirapine (substrate and inducer of CYP3A4 and 2B6) have also been studied. ${ }^{82}$ There was a clinically significant reduction in clearance of nevirapine when administered with fluvoxamine, and significantly decreased concentrations of fluoxetine when coadministered with nevirapine. Unlike other antidepressants with significant CYP activity, desvenlafaxine has low potential for interactions through PK mechanisms with HAART.

\section{Chronic pain}

Chronic pain and MDD have been found to have one of the strongest associations of occurrence, with a comorbid prevalence rate of about $31 \%{ }^{49,83}$

\section{Opioids}

In a study on DDIs with opioids, concomitant administration with antidepressants showed the highest potential for DDIs. ${ }^{84}$ As fentanyl, methadone, and oxycodone are major CYP3A4 substrates, inhibitors of this isoenzyme (Table 1) can cause increased effects of opioids. ${ }^{85,86}$ Another study identified increased levels of fentanyl derivatives with CYP3A4 inhibitors. ${ }^{84}$ In addition, there could be potential DDIs with CYP2D6 inhibitors (eg, paroxetine), as there are several opioids that are major substrates of CYP2D6 (eg, morphine, codeine). ${ }^{86,87}$ Tramadol instead undergoes extensive metabolism via both CYP2D6 and CYP3A4 enzymes. ${ }^{88}$ Desvenlafaxine does not seem to interfere in a major way with the CYP-metabolizing pathway of opioids, unlike other antidepressants, thus possibly reducing the risk of PK interactions. ${ }^{18}$

A higher occurrence of serotonin syndrome has been found when opioids, particularly tramadol, are coadministered with an SSRI or SNRI. ${ }^{63,89}$ This is because tramadol also has a possible SNRI effect. ${ }^{90}$ Consequently, there is a potential for PD interaction, as both desvenlafaxine and tramadol are serotonergic drugs. ${ }^{18}$ This interaction could also be conceivable with other serotonergic opioids, such as methadone, pethidine, and fentanyl. ${ }^{18,63}$ In contrast, morphine analogs like codeine and oxycodone have not been shown to inhibit the reuptake of serotonin. ${ }^{63}$

\section{Nonsteroidal anti-inflammatory drugs}

Many nonsteroidal anti-inflammatory drugs NSAIDs are metabolized by CYP enzymes, and thus their metabolism would be affected by antidepressants inhibiting the same 
enzymes (eg, CYP3A4, CYP2C9, CYP2D6). ${ }^{91-96}$ Conversely, some NSAIDs modestly inhibit CYP2C9 (eg, ibuprofen, indomethacin, diclofenac, meloxicam), CYP2C8/2D6 (eg, celecoxib), and glucuronidation (eg, ibuprofen, diclofenac), which may increase the concentrations of antidepressants dependent on these pathways for clearance (Table 1). ${ }^{91}$ Desvenlafaxine could possibly reduce the risks of such DDIs with NSAIDs related to PK mechanisms.

There are numerous documented DDIs of NSAIDs with antidepressants associated with increased bleeding and PK interactions. ${ }^{91} \mathrm{NICE}$ and American Psychiatric Association guidelines advise against SSRIs in patients taking NSAIDs because of the potentiated risk of gastrointestinal bleeding., ${ }^{4,23}$ A study showed that the risk of abnormal bleeding correlates with increasing degrees of serotonin-reuptake inhibition (eg, intermediate degree - venlafaxine, fluvoxamine, citalopram; high degree - fluoxetine, sertraline, paroxetine).$^{97}$ On the other hand, conflicting data regarding the association between SNRIs and potentiated gastrointestinal bleeding risk have been published. ${ }^{98,99}$ For desvenlafaxine in particular, although gastrointestinal bleeding is not documented as an adverse reaction, concomitant use of NSAIDs may add to this risk. ${ }^{18}$

\section{Chronic liver disease}

The overall prevalence of depression has been found to be $23.6 \%$ in patients with chronic liver disease $(27.2 \%$ in nonalcoholic fatty liver disease, $29.8 \%$ in hepatitis C, and 3.7\% in hepatitis B). ${ }^{100}$ Depression is also a common side effect of IFN $\alpha$ treatment (found in $30 \%-70 \%$ of treated patients). ${ }^{101}$ However, the association between chronic hepatitis $\mathrm{C}$ and MDD has been shown to be independent of treatment with IFN $\alpha .{ }^{102}$

Studies have shown modest inhibition of CYP1A2 by IFN $\alpha .{ }^{103}$ Directly acting antivirals also have inhibitory effects on the activities of CYP enzymes. ${ }^{104}$ Boceprevir, simeprevir, and telaprevir are substrates and inhibitors of CYP3A4. ${ }^{104,105}$ PK studies on escitalopram (CYP3A4 substrate) have shown no significant DDI with boceprevir, but a $35 \%$ decrease in exposure with telaprevir. ${ }^{106}$ There is a potential for increased sertraline, mirtazapine, and venlafaxine concentrations, due to CYP inhibition by the antiviral agents. ${ }^{106}$ Desvenlafaxine, showing minimal activity on the CYP metabolic pathway, could potentially mitigate such CYP-related PK interactions.

On the other hand, some directly acting antivirals, such as in the combination regimen of paritaprevir, ombitasvir, and dasabuvir, are UGT inhibitors. ${ }^{104}$ Interaction studies between these agents and furosemide (UGT1A1 substrate) have shown increased PK parameters of furosemide. ${ }^{104}$ This could imply a potential interaction in the metabolism of desvenlafaxine (Tables 1 and 2). ${ }^{106}$ However, no data regarding this are currently available.

Australian and New Zealand College of Psychiatrists 2015 practice guidelines ${ }^{26}$ recommended desvenlafaxine over other antidepressants (which are metabolized by the liver) for patients with hepatic impairments. This was based on a PK study that showed that single dose desvenlafaxine $100 \mathrm{mg}$ was well tolerated in both healthy subjects and liverimpaired patients. ${ }^{31}$

\section{Cancer}

The pooled prevalence of cancer and comorbid MDD from 31 studies was found to be $10.8 \%$ (range $3.7 \%-49 \%$ ), ${ }^{107}$ with increasing prevalence in cancers with poorer prognoses. ${ }^{57}$ Furthermore, more than $21 \%$ of patients who use concomitant oral anticancer agents and antidepressants within a three year period are on drug pairs that could potentially cause DDIs. ${ }^{108}$ Potential DDIs involving drug transporters and UGTs have not been identified as clinically important between anticancer agents and antidepressants. ${ }^{109}$ The following sections focus on DDIs with antiemetic and anticancer agents used in the most commonly diagnosed cancers worldwide, namely lung, breast, and colorectal cancer. ${ }^{110}$

\section{Antiemetic agents}

The metabolism of some $5 \mathrm{HT}_{3}$ antagonists, such as ondansetron, tropisetron, dolasetron, and palonosetron, involves CYP2D6. ${ }^{111}$ Granisetron does not depend on CYP2D6, but is a substrate of CYP3A4. ${ }^{111}$ In addition, corticosteroids, including dexamethasone, methylprednisolone, prednisolone, and prednisone, are also metabolized by CYP3A4. ${ }^{109}$ Antidepressants with CYP2D6/3A4-inhibitor activity (Table 1) could have DDIs with antiemetic agents. For instance, coadministration of fluoxetine has been shown to reduce the effectiveness of ondansetron. ${ }^{111}$ Based on PK profiles, desvenlafaxine could represent a rational choice in avoiding these interactions.

\section{Lung cancer}

Antimicrotubule agents, such as vinca alkaloids (eg, vincristine, vinblastine, and vinorelbine) and taxanes (eg, docetaxel and paclitaxel) are extensively metabolized by CYP3A4, potentially interacting with several antidepressants (Table 1). ${ }^{112}$ In cancer patients, coadministration of ketoconazole (CYP3A4 inhibitor) leads to decreased 
clearance of docetaxel by $49 \%$, resulting in toxicity and risk of febrile neutropenia. ${ }^{13}$ Therefore, antidepressants with inhibitory effect on CYP3A4 may have similar interactions with docetaxel. PK studies have shown that desvenlafaxine is not extensively metabolized by CYP3A4, and neither does it measurably alter CYP3A4-mediated metabolism. ${ }^{114}$

Clearance of the tyrosine-kinase inhibitors erlotinib and gefitinib is dependent on CYP3A4, and may be decreased with coadministration of CYP3A4 inhibitors (Table 1). Erlotinib may also be subjected to CYP1A2 inhibition by fluoxetine and fluvoxamine. ${ }^{115}$ Gefitinib has inhibitory activities on CYP2C19 and CYP2D6, and can decrease the clearance of CYP2D6 substrates, such as TCAs and venlafaxine. ${ }^{116,117}$ Similar but more profound effects have been noticed with another tyrosine-kinase inhibitor: imatinib (used for chronic myelogenous leukemia and gastrointestinal stromal tumors). ${ }^{118}$

\section{Breast cancer}

Cyclophosphamide and ifosfamide are both major substrates of CYP3A4 and CYP2B6, ${ }^{119}$ while doxorubicin is a major substrate of CYP3A4 and CYP2D6. ${ }^{120}$ Clinically significant interactions have been reported with inhibitors of these enzymes (Table 1), resulting in increased concentration and clinical effect of the anticancer agents. ${ }^{121}$ Tamoxifen, a commonly prescribed estrogen antagonist for hormone-positive breast cancer patients, ${ }^{122}$ relies on CYP2D6 for its biotransformation to the active metabolite. ${ }^{121}$ The use of paroxetine (potent CYP2D6 inhibitor) during tamoxifen treatment is associated with an increased risk of death by breast cancer, although venlafaxine does not seem to change this risk significantly. ${ }^{123}$ In 2010, the Committee for Medicinal Products for Human Use recommended physicians avoid using potent CYP2D6 inhibitors during tamoxifen treatment whenever possible. ${ }^{124}$ It is estimated that $20 \%-30 \%$ of women taking tamoxifen are also treated with antidepressants, magnifying the relevance of this DDI. ${ }^{121}$ For desvenlafaxine, studies have shown that it may represent a treatment that is unlikely to alter the metabolism of tamoxifen. ${ }^{125}$

\section{Colorectal cancer}

Irinotecan undergoes metabolism by CYP3A4 and also competitively inhibits this isoenzyme and CYP2C9. ${ }^{126}$ A case report showed potentially fatal rhabdomyolysis that occurred in a patient who was coadministered with irinotecan and citalopram (CYP3A4 substrate). ${ }^{127}$ This speculates a theoretical PK interaction between irinotecan and other CYP3A4 substrates, such as escitalopram and fluoxetine. ${ }^{117}$
Desvenlafaxine is only a minor substrate of CYP3A4, and is not expected to be majorly involved in this interaction.

\section{Conclusion}

The coprevalence of chronic physical conditions and depression is very common. The potential for DDIs should be considered when selecting treatment options in patients with multiple comorbidities. This is crucial for achieving optimal patient adherence and outcomes.

The majority of SSRIs undergo extensive hepatic oxidative metabolism mediated by CYP450 isoenzymes. As such, many clinically significant DDIs have been reported, mostly due to inhibition of these enzymes. While SSRIs such as fluoxetine and paroxetine are potent inhibitors of CYP2D6, fluvoxamine is a potent inhibitor of CYP1A2 and CYP2C19, and these SSRIs are thus likely to cause DDIs. Other SSRIs, such as sertraline, citalopram, and escitalopram, at usual therapeutic dosages are probably less likely to cause significant alterations in CYP450 status. However, even these interactions may be clinically significant in specific patient populations, eg, in renally and hepatically impaired patients, poor/intermediate CYP metabolizers, or for drugs with a narrow therapeutic range.

The simple metabolic pathway of desvenlafaxine compared to other antidepressants may make it favorable in avoiding CYP-related PK interactions with drugs of many therapeutic classes. However, relevant PD interactions with desvenlafaxine, eg, elevated blood pressure and heart rate, abnormal bleeding, and serotonin syndrome, should be closely monitored in practice.

\section{Acknowledgments}

The authors would like to thank Dr Matthieu Boucher, Medical Affairs, Pfizer Canada Inc, for his valuable comments and review of the manuscript.

\section{Author contributions}

All authors were involved in conception, design, analysis, interpretation of data, preparation of the manuscript, revising it for important intellectual content, and final approval before submitting it for publication.

\section{Disclosure}

SS and GL are employees of Pfizer, manufacturer of desvenlafaxine. YL underwent indirect patient-care pharmacy training for 3 months at Pfizer, Singapore. The authors report no other conflicts of interest in this work. 


\section{References}

1. American Psychiatric Association. Diagnostic and Statistical Manual of Mental Disorders. 5th ed. Arlington (VA): APA; 2013.

2. World Health Organization. Depression. 2017. Available from: http:// www.who.int/mediacentre/factsheets/fs369/en. Accessed May 30, 2017

3. Kang HJ, Kim SY, Bae KY, et al. Comorbidity of depression with physical disorders: research and clinical implications. Chonnam MedJ. 2015;51(1):8-18.

4. National Institute for Health and Care Excellence. Depression in Adults with a Chronic Physical Health Problem: Recognition and Management. London: NICE; 2009.

5. Kessler RC, Birnbaum HG, Shahly V, et al. Age differences in the prevalence and co-morbidity of DSM-IV major depressive episodes: results from the WHO World Mental Health Survey Initiative. Depress Anxiety. 2010;27(4):351-364.

6. Rodrigues MC, de Oliveira C. Drug-drug interactions and adverse drug reactions in polypharmacy among older adults: an integrative review. Rev Lat Am Enfermagem. 2016;24:e2800.

7. Palleria C, Di Paolo A, Giofrè C, et al. Pharmacokinetic drug-drug interaction and their implication in clinical management. J Res Med Sci. 2013;18(7):601-610

8. Kennedy C, Brewer L, Williams D. Drug interactions. Medicine. 2016; 44(7):422-426.

9. Zanger UM, Raimundo S, Eichelbaum M. Cytochrome P450 2D6: overview and update on pharmacology, genetics, biochemistry. Naunyn Schmiedebergs Arch Pharmacol. 2004;369(1):23-37.

10. Scheen AJ. Cytochrome P450-mediated cardiovascular drug interactions. Expert Opin Drug Metab Toxicol. 2011;7(9):1065-1082.

11. Mulder H, Heerdink ER, van Iersel EE, Wilmink FW, Egberts AC. Prevalence of patients using drugs metabolized by cytochrome P450 2D6 in different populations: a cross-sectional study. Ann Pharmacother. 2007; 41(3):408-413.

12. Preskorn SH, Nichols AI, Paul J, Patroneva AL, Helzner EC, Guico-Pabia CJ. Effect of desvenlafaxine on the cytochrome P450 2D6 enzyme system. J Psychiatr Pract. 2008;14(6):368-378.

13. Preskorn SH, Kane CP, Lobello K, et al. Cytochrome P450 2D6 phenoconversion is common in patients being treated for depression: implications for personalized medicine. J Clin Psychiatry. 2013;74(6): 614-621.

14. Manolopoulos VG, Ragia G, Alevizopoulos G. Pharmacokinetic interactions of selective serotonin reuptake inhibitors with other commonly prescribed drugs in the era of pharmacogenomics. Drug Metabol Drug Interact. 2012;27(1):19-31.

15. Martin J, Lee KC. Pharmacogenomics of antidepressants for major depressive disorder. Ment Health Clin. 2012;1(9):222-224.

16. English BA, Dortch M, Ereshefsky L, Jhee S. Clinically significant psychotropic drug-drug interactions in the primary care setting. Curr Psychiatry Rep. 2012;14(4):376-390.

17. Preskorn SH, Flockhart D. The Black Book of Psychiatric Drug Interactions. New York: MBL Communications; 2010.

18. Pristiq (desvenlafaxine) extended release tablets [prescribing information]. Singapore: Pfizer; 2016.

19. Carrasco JL, Kornstein SG, McIntyre RS, et al. An integrated analysis of the efficacy and safety of desvenlafaxine in the treatment of major depressive disorder. Int Clin Psychopharmacol. 2016;31(3):134-146.

20. Gupta BM, Zargar SH, Arora M, Tandon VR. Efficacy and safety of escitalopram versus desvenlafaxine in the treatment of major depression: a preliminary 1-year prospective randomized open label comparative trial. Perspect Clin Res. 2016;7(1):45-50.

21. Soares CN, Thase ME, Clayton A, et al. Desvenlafaxine and escitalopram for the treatment of postmenopausal women with major depressive disorder. Menopause. 2010;17(4):700-711.

22. Soares CN, Thase ME, Clayton A, et al. Open-label treatment with desvenlafaxine in postmenopausal women with major depressive disorder not responding to acute treatment with desvenlafaxine or escitalopram. CNS Drugs. 2011;25(3):227-238.
23. Gelenberg A, Freeman M, Markowitz JC, et al. Practice Guideline for the Treatment of Patients with Major Depressive Disorder. 3rd ed. Arlington (VA): American Psychiatric Association; 2010.

24. Kennedy SH, Lam RW, McIntyre RS, et al. Canadian Network for Mood and Anxiety Treatments (CANMAT) 2016 clinical guidelines for the management of adults with major depressive disorder - section 3: pharmacological treatments. Can J Psychiatry. 2016;61(9):540-560.

25. Lam RW, Kennedy SH, Grigoriadis S, et al. Canadian Network for Mood and Anxiety Treatments (CANMAT) clinical guidelines for the management of major depressive disorder in adults - III: pharmacotherapy. J Affect Disord. 2009;117(Suppl 1):S26-S43.

26. Malhi GS, Bassett D, Boyce P, et al. Royal Australian and New Zealand College of Psychiatrists clinical practice guidelines for mood disorders. Aust N Z J Psychiatry. 2015;49(12):1-185.

27. Sangkuhl K, Stingl JC, Turpeinen M, Altman RB, Klein TE. PharmGKB summary: venlafaxine pathway. Pharmacogenet Genomics. 2014;24(1):62-72.

28. DeMaio W, Kane CP, Nichols AI, Jordan R. Metabolism studies of desvenlafaxine. J Bioequiv Availab. 2011;3:151-160.

29. Macaluso M, Nichols AI, Preskorn SH. How the probability and potential clinical significance of pharmacokinetically mediated drugdrug interactions are assessed in drug development: desvenlafaxine as an example. Prim Care Companion CNS Disord. 2015;17(2):10.4088/ PCC.4014r01710.

30. Congiu M, Mashford ML, Slavin JL, Desmond PV. UDP glucuronosyltransferase mRNA levels in human liver disease. Drug Metab Dispos. 2002;30(2):129-134.

31. Baird-Bellaire S, Behrle JA, Parker VD, Patat A, Paul J, Nichols AI. An open-label, single-dose, parallel-group study of the effects of chronic hepatic impairment on the safety and pharmacokinetics of desvenlafaxine. Clin Ther. 2013;35(6):782-794.

32. Nichols AI, Richards LS, Behrle JA, Posener JA, McGrory SB, Paul J. The pharmacokinetics and safety of desvenlafaxine in subjects with chronic renal impairment. Int J Clin Pharmacol Ther. 2011; 49(1):3-13.

33. Flockhart DA. Drug interactions: defining genetic influences on pharmacologic responses - cytochrome P450 drug interaction table. 2007. Available from: http://medicine.iupui.edu/clinpharm/ddis. Accessed June 7, 2017.

34. Spina E, Pisani F, de Leon J. Clinically significant pharmacokinetic drug interactions of antiepileptic drugs with new antidepressants and new antipsychotics. Pharmacol Res. 2016;106:72-86.

35. Dumbreck S, Flynn A, Nairn M, et al. Drug-disease and drug-drug interactions: systematic examination of recommendations in 12 UK national clinical guidelines. BMJ. 2015;350:h949.

36. Lugtenberg M, Burgers JS, Clancy C, Westert GP, Schneider EC. Current guidelines have limited applicability to patients with comorbid conditions: a systematic analysis of evidence-based guidelines PLoS One. 2011;6(10):e25987.

37. Lam RW, Kennedy SH, Sareen J, Yatham LN. Why are there no treatment guidelines for mood disorders and comorbidities? Ann Clin Psychiatry. 2012;24(1):4-5.

38. Glassman AH. Depression and cardiovascular comorbidity. Dialogues Clin Neurosci. 2007;9(1):9-17.

39. Flockhart DA, Tanus-Santos JE. Implications of cytochrome P450 interactions when prescribing medication for hypertension. Arch Intern Med. 2002;162(4):405-412.

40. Bahar MA, Hak E, Bos JH, Borgsteede SD, Wilffert B. The burden and management of cytochrome P450 2D6 (CYP2D6)-mediated drugdrug interaction (DDI): co-medication of metoprolol and paroxetine or fluoxetine in the elderly. Pharmacoepidemiol Drug Saf. 2017;26(7): $752-765$.

41. Trujillo TC, Nolan PE. Antiarrhythmic agents: drug interactions of clinical significance. Drug Saf. 2000;23(6):509-532.

42. Holbrook AM, Pereira JA, Labiris R, et al. Systematic overview of warfarin and its drug and food interactions. Arch Intern Med. 2005; 165(10):1095-1106. 
43. Dong YH, Bykov K, Choudhry NK, et al. Clinical outcomes of concomitant use of warfarin and selective serotonin reuptake inhibitors: a multidatabase observational cohort study. J Clin Psychopharmacol. 2017;37(2):200-209.

44. Walenga JM, Adiguzel C. Drug and dietary interactions of the new and emerging oral anticoagulants. Int J Clin Pract. 2010;64(7):956-967.

45. Derijks HJ, Heerdink ER, De Koning FH, Janknegt R, Klungel OH, Egberts AC. The association between antidepressant use and hypoglycaemia in diabetic patients: a nested case-control study. Pharmacoepidemiol Drug Saf. 2008;17(4):336-344.

46. Moulton CD, Pickup JC, Ismail K. The link between depression and diabetes: the search for shared mechanisms. Lancet Diabetes Endocrinol. 2015;3(6):461-471.

47. Madsen H, Enggaard TP, Hansen LL, Klitgaard NA, Brosen K. Fluvoxamine inhibits the CYP2C9 catalyzed biotransformation of tolbutamide. Clin Pharmacol Ther. 2001;69(1):41-47.

48. Tirkkonen T, Heikkila P, Huupponen R, Laine K. Potential CYP2C9mediated drug-drug interactions in hospitalized type 2 diabetes mellitus patients treated with the sulphonylureas glibenclamide, glimepiride or glipizide. J Intern Med. 2010;268(4):359-366.

49. Guthrie B, Payne K, Alderson P, McMurdo ME, Mercer SW. Adapting clinical guidelines to take account of multimorbidity. BMJ. 2012; 345:e6341.

50. Kanagaratnam L, Mahmoudi R, Novella JL, Jolly D, Dramé M, Trenque T. Adverse drug reactions in elderly subjects hospitalized in a specialized dementia management unit. Drugs Aging. 2014;31(10): 769-776.

51. Pasqualetti G, Tognini S, Calsolaro V, Polini A, Monzani F. Potential drug-drug interactions in Alzheimer patients with behavioral symptoms. Clin Interv Aging. 2015;10:1457-1466.

52. Kornhuber J, Kennepohl EM, Bleich S, et al. Memantine pharmacotherapy: a naturalistic study using a population pharmacokinetic approach. Clin Pharmacokinet. 2007;46(7):599-612.

53. Trivedi MH, Kurian BT. Managing depressive disorders in patients with epilepsy. Psychiatry (Edgmont). 2007;4(1):26-34.

54. Tellez-Zenteno JF, Patten SB, Jette N, Williams J, Wiebe S. Psychiatric comorbidity in epilepsy: a population-based analysis. Epilepsia. 2007; 48(12):2336-2344.

55. de Leon J. The effects of antiepileptic inducers in neuropsychopharmacology, a neglected issue - part I: a summary of the current state for clinicians. Rev Psiquiatr Salud Ment. 2015;8(2):97-115.

56. Landmark CJ, Patsalos PN. Drug interactions involving the new secondand third-generation antiepileptic drugs. Expert Rev Neurother. 2010; 10(1):119-140.

57. Ramasubbu R, Taylor VH, Samaan Z, et al. The Canadian Network for Mood and Anxiety Treatments (CANMAT) task force recommendations for the management of patients with mood disorders and select comorbid medical conditions. Ann Clin Psychiatry. 2012;24(1): 91-109.

58. Jette N, Patten S, Williams J, Becker W, Wiebe S. Comorbidity of migraine and psychiatric disorders: a national population-based study. Headache. 2008;48(4):501-516.

59. Kalaydjian A, Merikangas K. Physical and mental comorbidity of headache in a nationally representative sample of U.S. adults. Psychosom Med. 2008;70(7):773-780.

60. Napoletano F, Lionetto L, Martelletti P. Sumatriptan in clinical practice: effectiveness in migraine and the problem of psychiatric comorbidity. Expert Opin Pharmacother. 2014;15(3):303-305.

61. Rolan PE. Drug interactions with triptans. CNS Drugs. 2012;26(11): 949-957.

62. Tepper S, Allen C, Sanders D, Greene A, Boccuzzi S. Coprescription of triptans with potentially interacting medications: a cohort study involving 240268 patients. Headache. 2003;43(1):44-48.

63. Ansari H, Kouti L. Drug interaction and serotonin toxicity with opioid use: another reason to avoid opioids in headache and migraine treatment. Curr Pain Headache Rep. 2016;20(8):50.
64. Evans RW, Tepper SJ, Shapiro RE, Sun-Edelstein C, Tietjen GE. The FDA alert on serotonin syndrome with use of triptans combined with selective serotonin reuptake inhibitors or selective serotoninnorepinephrine reuptake inhibitors: American Headache Society position paper. Headache. 2010;50(6):1089-1099.

65. Kogut SJ. Do triptan antimigraine medications interact with SSRI/ SNRI antidepressants? What does your decision support system say? J Manag Care Pharm. 2011;17(7):547-551.

66. Imigran (sumatriptan) film-coated tablet [prescribing information]. Singapore: GlaxoSmithKline; 2015.

67. Evans RW. The FDA alert on serotonin syndrome with combined use of SSRIs or SNRIs and triptans: an analysis of the 29 case reports. MedGenMed. 2007;9(3):48.

68. Spina E, de Leon J. Clinically relevant interactions between newer antidepressants and second-generation antipsychotics. Expert Opin Drug Metab Toxicol. 2014;10(5):721-746.

69. Spina E, de Leon J. Metabolic drug interactions with newer antipsychotics: a comparative review. Basic Clin Pharmacol Toxicol. 2007; 100(1):4-22.

70. Bork JA, Rogers T, Wedlund PJ, de Leon J. A pilot study on risperidone metabolism: the role of cytochromes P450 2D6 and 3A. J Clin Psychiatry. 1999;60(7):469-476.

71. Avenoso A, Facciolà G, Scordo MG, et al. No effect of citalopram on plasma levels of clozapine, risperidone and their active metabolites in patients with chronic schizophrenia. Clin Drug Investig. 1998;16(5): 393-398.

72. Urichuk L, Prior TI, Dursun S, Baker G. Metabolism of atypical antipsychotics: involvement of cytochrome p450 enzymes and relevance for drug-drug interactions. Curr Drug Metab. 2008;9(5):410-418.

73. Boulton DW, Balch AH, Royzman K, et al. The pharmacokinetics of standard antidepressants with aripiprazole as adjunctive therapy: studies in healthy subjects and in patients with major depressive disorder. J Psychopharmacol. 2010;24(4):537-546.

74. Chibanda D. Depression and HIV: integrated care towards 90-90-90. Int Health. 2017;9(2):77-79.

75. Tao J, Vermund SH, Qian HZ. Association between depression and antiretroviral therapy use among people living with HIV: a metaanalysis. AIDS Behav. Epub 2017 Apr 24.

76. DeSilva KE, Le Flore DB, Marston BJ, Rimland D. Serotonin syndrome in HIV-infected individuals receiving antiretroviral therapy and fluoxetine. AIDS. 2001;15(10):1281-1285.

77. Hill L, Lee KC. Pharmacotherapy considerations in patients with HIV and psychiatric disorders: focus on antidepressants and antipsychotics. Ann Pharmacother. 2013;47(1):75-89.

78. Norvir (ritonavir) film-coated tablet [prescribing information]. Singapore: AbbVie; 2016.

79. Gutierrez MM, Rosenberg J, Abramowitz W. An evaluation of the potential for pharmacokinetic interaction between escitalopram and the cytochrome P450 3A4 inhibitor ritonavir. Clin Ther. 2003;25(4): $1200-1210$

80. Crixivan (indinavir) capsules [prescribing information]. Singapore: MSD Pharma; 2012.

81. Jann MW, Spratlin V, Momary K, et al. Lack of a pharmacokinetic drug-drug interaction with venlafaxine extended-release/indinavir and desvenlafaxine extended-release/indinavir. Eur J Clin Pharmacol. 2012;68(5):715-721.

82. de Maat MM, Huitema AD, Mulder JW, et al. Drug interaction of fluvoxamine and fluoxetine with nevirapine in HIV-1-infected individuals. Clin Drug Investig. 2003;23(10):629-637.

83. Patten SB, Beck CA, Kassam A, Williams JV, Barbui C, Metz LM. Long-term medical conditions and major depression: strength of association for specific conditions in the general population. Can $J$ Psychiatry. 2005;50(4):195-202.

84. Siebenhuener K, Eschmann E, Kienast A, et al. Chronic pain: how challenging are DDIs in the analgesic treatment of inpatients with multiple chronic conditions? PloS One. 2017;12(1):e0168987. 
85. Durogesic (fentanyl) transdermal patch [prescribing information]. Singapore: Johnson \& Johnson; 2017.

86. Lotsch J, Skarke C, Tegeder I, Geisslinger G. Drug interactions with patient-controlled analgesia. Clin Pharmacokinet. 2002;41(1): 31-57.

87. Pergolizzi JV Jr, Ma L, Foster DR, et al. The prevalence of opioid-related major potential drug-drug interactions and their impact on health care costs in chronic pain patients. J Manag Care Spec Pharm. 2014; 20(5):467-476.

88. Durotram (tramadol hydrochloride) extended release tablets [prescribing information]. Singapore: Inova Pharmaceuticals; 2015.

89. Gnanadesigan N, Espinoza RT, Smith R, Israel M, Reuben DB. Interaction of serotonergic antidepressants and opioid analgesics: is serotonin syndrome going undetected? J Am Med Dir Assoc. 2005;6(4): 265-269.

90. Grond S, Sablotzki A. Clinical pharmacology of tramadol. Clin Pharmacokinet. 2004;43(13):879-923.

91. Solomon DH. NSAIDs: therapeutic use and variability of response in adults. 2017. Available from: https://www.uptodate.com/contents/ nsaids-therapeutic-use-and-variability-of-response-in-adults. Accessed June 13, 2017.

92. Arcoxia (etoricoxib) film-coated tablets [prescribing information]. Singapore: MSD Pharma; 2015.

93. Celebrex (celecoxib) capsules [prescribing information]. Singapore: Pfizer; 2016.

94. Nurofen (Ibuprofen) sugar-coated tablet [prescribing information]. Singapore: Reckitt Benckiser; 2015.

95. Voltaren (diclofenac) film-coated tablet [prescribing information]. Singapore: Novartis; 2016.

96. Aleve (naproxen) film-coated tablet [prescribing information]. Singapore: Bayer; 2015.

97. Meijer WE, Heerdink ER, Nolen WA, Herings RM, Leufkens HG, Egberts AC. Association of risk of abnormal bleeding with degree of serotonin reuptake inhibition by antidepressants. Arch Intern Med. 2004;164(21):2367-2370.

98. Cheng YL, Hu HY, Lin XH, et al. Use of SSRI, but not SNRI, increased upper and lower gastrointestinal bleeding: a nationwide population-based cohort study in Taiwan. Medicine (Baltimore). 2015; 94(46): 2022

99. de Abajo FJ, Garcia-Rodriguez LA. Risk of upper gastrointestinal tract bleeding associated with selective serotonin reuptake inhibitors and venlafaxine therapy: interaction with nonsteroidal anti-inflammatory drugs and effect of acid-suppressing agents. Arch Gen Psychiatry. 2008; 65(7):795-803

100. Weinstein AA, Kallman Price J, Stepanova M, et al. Depression in patients with nonalcoholic fatty liver disease and chronic viral hepatitis B and C. Psychosomatics. 2011;52(2):127-132.

101. Schaefer M, Capuron L, Friebe A, et al. Hepatitis C infection, antiviral treatment and mental health: a European expert consensus statement. J Hepatol. 2012;57(6):1379-1390.

102. Carta MG, Hardoy MC, Garofalo A, et al. Association of chronic hepatitis $\mathrm{C}$ with major depressive disorders: irrespective of interferon- $\alpha$ therapy. Clin Pract Epidemiol Ment Health. 2007;3:22.

103. Pegasys (PEG-interferon $\alpha 2 a$ ) subcutaneous injection [prescribing information]. Singapore: Roche; 2017.

104. Smolders EJ, de Kanter CT, de Knegt RJ, van der Valk M, Drenth JP, Burger DM. Drug-drug interactions between directacting antivirals and psychoactive medications. Clin Pharmacokinet. 2016;55(12):1471-1494.

105. Victrelis (boceprevir) capsule [prescribing information]. Singapore: MSD Pharma; 2017.

106. Sockalingam S, Tseng A, Giguere P, Wong D. Psychiatric treatment considerations with direct acting antivirals in hepatitis C. $B M C$ Gastroenterol. 2013;13:86.
107. Ng CG, Boks MPM, Zainal NZ, de Wit NJ. The prevalence and pharmacotherapy of depression in cancer patients. J Affect Disord. 2011; 131(1-3):1-7.

108. Chan A, Yap KY, Koh D, Low XH, Cheung YT. Electronic database to detect drug-drug interactions between antidepressants and oral anticancer drugs from a cancer center in Singapore: implications to clinicians. Pharmacoepidemiol Drug Saf. 2011;20(9):939-947.

109. Chan A, Ng TR, Yap KY.Clinically-relevant anticancer-antidepressantdrug interactions. Expert Opin Drug Metab Toxicol. 2012;8(2):173-199.

110. Ferlay J, Soerjomataram I, Dikshit R, et al. Cancer incidence and mortality worldwide: sources, methods and major patterns in GLOBOCAN 2012. Int J Cancer. 2015;136(5):E359-E386.

111. Blower P, de Wit R, Goodin S, Aapro M. Drug-drug interactions in oncology: why are they important and can they be minimized? Crit Rev Oncol Hematol. 2005;55(2):117-142.

112. Beijnen JH, Schellens JHM. Drug interactions in oncology. Lancet Oncol. 2004;5(8):489-496.

113. Engels FK, Ten Tije AJ, Baker SD, et al. Effect of cytochrome P450 3A4 inhibition on the pharmacokinetics of docetaxel. Clin Pharmacol Ther. 2004;75(5):448-454.

114. Nichols A, Liang Y, Matschke K, et al. An evaluation of the potential of cytochrome P450 3A4-mediated drug-drug interactions with desvenlafaxine use. J Bioequiv Availab. 2013;5:53-59.

115. Tarceva (erlotinib) film-coated tablet [prescribing information] Singapore: Roche; 2016.

116. Iressa (gefitinib) film-coated tablet [prescribing information]. Singapore: AstraZeneca; 2017.

117. Yap KY, Tay WL, Chui WK, Chan A. Clinically relevant drug interactions between anticancer drugs and psychotropic agents. Eur J Cancer Care. 2011;20(1):6-32.

118. Glivec (imatinib) film-coated tablet [prescribing information]. Singapore: Novartis; 2016

119. Boddy AV, Yule SM. Metabolism and pharmacokinetics of oxazaphosphorines. Clin Pharmacokinet. 2000;38(4):291-304.

120. Adriamycin (doxorubicin) intravenous injection [prescribing information]. Singapore: Pfizer; 2015.

121. Caraci F, Crupi R, Drago F, Spina E. Metabolic drug interactions between antidepressants and anticancer drugs: focus on selective serotonin reuptake inhibitors and Hypericum extract. Curr Drug Metab. 2011;12(6):570-577.

122. Colleoni M, Gelber S, Goldhirsch A, et al. Tamoxifen after adjuvant chemotherapy for premenopausal women with lymph node-positive breast cancer: International Breast Cancer Study Group Trial 13-93. J Clin Oncol. 2006;24(9):1332-1341.

123. Kelly CM, Juurlink DN, Gomes T, et al. Selective serotonin reuptake inhibitors and breast cancer mortality in women receiving tamoxifen: a population based cohort study. BMJ. 2010;340:c693.

124. European Medicines Agency. CHMP Pharmacovigilance Working Party (PhVWP): September 2010 plenary meeting. 2010. Available from: http://www.ema.europa.eu/docs/en_GB/document_library/ Report/2010/10/WC500097444.pdf. Accessed July 27, 2017.

125. Nichols AI, Lubaczewski S, Liang Y, Matschke K, Braley G, Ramey T. Open-label, 2-period sequential drug interaction study to evaluate the effect of a 100-mg dose of desvenlafaxine on the pharmacokinetics of tamoxifen when coadministered in healthy postmenopausal female subjects. Int J Clin Pharmacol Ther. 2014;52(10):830-841.

126. Campto (irinotecan) intravenous injection [prescribing information] Singapore: Pfizer; 2014.

127. Richards S, Umbreit JN, Fanucchi MP, Giblin J, Khuri F. Selective serotonin reuptake inhibitor-induced rhabdomyolysis associated with irinotecan. South Med J. 2003;96(10):1031-1033.

128. Sunvepra (asunaprevir) capsule [prescribing information]. Singapore: Bristol-Myers Squibb; 2016.

129. Olysio (simprevir) capsule [prescribing information]. Singapore: Johnson \& Johnson; 2017. 


\section{Publish your work in this journal}

Neuropsychiatric Disease and Treatment is an international, peerreviewed journal of clinical therapeutics and pharmacology focusing on concise rapid reporting of clinical or pre-clinical studies on a range of neuropsychiatric and neurological disorders. This journal is indexed on PubMed Central, the 'PsycINFO' database and CAS, and is the official journal of The International Neuropsychiatric Association (INA). The manuscript management system is completely online and includes a very quick and fair peer-review system, which is all easy to use. Visit http://www.dovepress.com/testimonials.php to read real quotes from published authors.

\footnotetext{
Submit your manuscript here: http://www.dovepress.com/neuropsychiatric-disease-and-treatment-journal
} 